DIGITAL COMMONS
@ UNIVERSITY OF SOUTH FLORIDA

Volume 2

Issue 2 Volume 2.2 (Fall 2012): Open Access

\section{ABO: Interactive Journal for Women in the Arts, 1640-1830}

2012

\title{
Populism, Gender, and Sympathy in the Romantic Novel, by James P. Carson
}

\author{
Elizabeth J. Mathews \\ University of California, Irvine, elizabethjmathews@gmail.com
}

Follow this and additional works at: https://digitalcommons.usf.edu/abo

Part of the Dramatic Literature, Criticism and Theory Commons, Educational Methods Commons, Feminist, Gender, and Sexuality Studies Commons, and the Literature in English, British Isles Commons

\section{Recommended Citation \\ Mathews, Elizabeth J. (2012) "Populism, Gender, and Sympathy in the Romantic Novel, by James P. Carson," ABO: Interactive Journal for Women in the Arts, 1640-1830: Vol.2: Iss.2, Article 13. http://dx.doi.org/10.5038/2157-7129.2.2.13 \\ Available at: https://digitalcommons.usf.edu/abo/vol2/iss2/13}

This Reviews is brought to you for free and open access by Digital Commons @ University of South Florida. It has been accepted for inclusion in ABO: Interactive Journal for Women in the Arts, 1640-1830 by an authorized administrator of Digital Commons @ University of South Florida. For more information, please contact digitalcommons@usf.edu. 


\section{Populism, Gender, and Sympathy in the Romantic Novel, by James P. Carson}

\section{Keywords}

crowds, gender, novel, Populism, review, romantic novel, Romanticism, sound, sympathy

Creative Commons License

(c) $($ ) $\odot$

This work is licensed under a Creative Commons Attribution-No Derivative Works 3.0 License. 
James P. Carson. Populism, Gender, and Sympathy in the Romantic Novel. New York: Palgrave Macmillan, 2010. \$80.00. 260 pp. ISBN 978-0-230-62110-7.

Reviewed by Elizabeth J. Mathews, University of California, Irvine

In his intriguing book, Populism, Gender, and Sympathy in the Romantic Novel, James P. Carson reads Romantic novels in a biographical, historical, and political context, exploring the representation of crowds. He reveals the ambivalence of Romantic authors on issues of gender, popular culture, and social control. By focusing primarily on the masses rather than the individual and on sound rather than vision, the book offers a fresh perspective on the social and political issues at stake in late-eighteenth-century and early nineteenth-century fiction.

Carson begins the book with a description of the ancient ear of Dionysius, an elaborate earshaped cavern written about in a travel memoir from 1773, which was used for auditory surveillance, and his study features sound throughout. The theme of sound could be more integrated into the book as a whole, but it provides a fascinating thread through the chapters, tying to eavesdropping, sympathy, voice, and oral culture.

Chapter 1, "Gothic and Romantic Crowds," justifies the book's exploration of the masses rather than the individual. Carson frames the difference between Gothic and Romantic modes as a disagreement over values inherent in attempts to represent people. He discusses the Wordsworthian method of focusing on a common individual object or creating unity from a multitude in an attempt to restore singularity, employ imagination, and evoke deep feeling in the midst of excess. In contrast, he argues, the Gothic novel embraces excess, using the methods of division and distraction to create multiple identifications.

In chapter 2, "Popular versus Legitimate Authority in Scott's The Heart of the Mid-Lothian," Carson explores gendered authority, particularly representations of women and popular protest. The chapter discusses historical accounts of women rioting, in which women appear as abject and transgressive, and traditions and representations of cross-dressing. Carson examines Walter Scott's conflicted relationship with crowds and women inhabiting roles of authority, whether as warriors or as writers. Scott's depictions of savagery and assertions of social control rival his populist sympathy and feminine literary influences.

Chapter 3 is titled "Gothic Properties: Matthew Lewis's The Monk and Journal of a West India Proprietor," and it juxtaposes Lewis's fiction with his account of his life to expose the conflict between his fictional and personal ethics while revisiting the traditional rhetorical connection between women and slaves. Carson argues that Lewis's Gothic novel forms a critique of gendered sovereignty as well as humane modes of social control and that his later experience as a slaveholder replays these already explored conflicts. Carson draws on psychoanalysis in his discussion of Lewis's attitudes toward women, and he reflects on the Gothic novel's concern with race and disciplinary power.

Chapter 4, "Unisonance and the Echo: Popular Disturbances and Theatricality in the Works of Charles Maturin," the Irish writer and clergyman forms the nucleus of a discussion of gender, 
nationalism, rebellion, and sound. Carson asserts that Maturin's fiction and letters conflict with his sermons. He argues that Maturin found the united voice of the crowd to be both hopeful and threatening and discusses the formation of a "sentimental nationalism." And while Maturin's view on the proper role of women remains fairly rigid across his work, Carson points out his persistent fascination with the figure of the cross-dressing, transgressive woman.

In chapter 5, “Godwin's 'Metaphysical Dissecting Knife,'” Carson uses William Godwin's metaphor for first-person narration, discussing the psychological violence that can result from attempts to enter people's minds. This chapter would benefit from being in conversation with Ann Jessie Van Sant's work on the relationship between sympathetic curiosity and experimental curiosity in the eighteenth century, which would complement Carson's analysis of Godwin's views on truth seeking.

Chapter 6, “'A Sigh of Many Hearts': History, Humanity, and Popular Culture in Mary Shelley's Valperga and Lodore," follows the previous chapter's discussion of Godwin and Mary Wollstonecraft with an analysis of their daughter's writing on gender, crowds, and sensibility. Carson examines Shelley's concern with issues of humanity through the lenses of republican politics and sentimental literary tradition. He argues that, contra Shelley's detractors, her work represents liberal ideals and that while she acknowledges unsavory aspects of the crowd and popular culture, she also reveals sympathy for them.

The book concludes with a discussion of sound and sight, reviewing assertions about subjectivity, sympathy, gender, and masses.

Carson's book ranges widely. Several themes recur: representations of the crowd, popular violence, and popular culture, and the female gendering of these phenomena; cross-dressing and anxieties about women's access to power and authority; issues of social control, especially as it relates to gender, class, and race; the complexities of ideology that become visible when considering an author's life and body of work; and the complications inherent in sympathy. Sound weaves through many of these themes, sometimes producing surprising insights. While the multiplicity of possible areas of focus can sometimes overwhelm, Carson provides helpful overviews, drawing together many disparate elements into a complex and satisfying whole. 